This item was submitted to Loughborough's Research Repository by the author.

Items in Figshare are protected by copyright, with all rights reserved, unless otherwise indicated.

\title{
The financialisation of local governments: Evidence from the Italian case
}

PLEASE CITE THE PUBLISHED VERSION

https://www.routledge.com/The-Routledge-Companion-to-Banking-Regulation-and-Reform/Erturk-

Gabor/p/book/9780415855938

\section{PUBLISHER}

Routledge

VERSION

AM (Accepted Manuscript)

\section{PUBLISHER STATEMENT}

This work is made available according to the conditions of the Creative Commons Attribution-NonCommercialNoDerivatives 4.0 International (CC BY-NC-ND 4.0) licence. Full details of this licence are available at: https://creativecommons.org/licenses/by-nc-nd/4.0/

\section{LICENCE}

CC BY-NC-ND 4.0

\section{REPOSITORY RECORD}

Lagna, Andrea. 2019. "The Financialisation of Local Governments: Evidence from the Italian Case". figshare. https://hdl.handle.net/2134/37320. 
$<\mathrm{CN}>11$

$<$ CT > The financialisation of local governments: evidence from the Italian case

$<\mathrm{CA}>$ Andrea Lagna

Derivatives markets emblematically reflect the rise of finance in modern capitalism (Bryan and Rafferty, 2006; Wigan, 2009, a multi-faceted process known as financialisation (Engelen, 2008). The notional value of global overthe-counter (OTC) derivatives was $\$ 553$ trillion at the end of June 2015 (BIS, 2015). This huge sum raises questions concerning why individuals use derivatives and how these practices spread differentially across the world. In this chapter, I examine how the expansion of derivatives markets, actors and technologies in Italy caused havoc amongst local governments, one the most important institutions of democratic life. By examining this case study, I argue that specific political struggles shape the global growth of derivatives - and financial innovation more broadly - into a complex and uneven process. Whether implicitly or explicitly, mainstream financial theory considers the development of derivatives markets in ahistorical terms. It refers to how derivatives and their speculative mechanisms provide investors with useful solutions to hedge risk in a calculated manner (Greenspan, 2003). Against this orthodox narrative, I demonstrate that actual politics and power relations underlie market-based financial innovation and its crisis-prone nature (Nölke, Heires and Bieling, 2013; Konings, 2010).

The analysis proceeds in three steps. In the first section, I rethink derivatives markets, instruments and actors as a universe of accounting deception. This facet of derivatives is very apt in the context of power 
struggles. In the second section, I examine the political-strategic reasons underpinning Italian municipalities and their overexposure to interest rate swaps. In the third section, I conclude by reviewing the current Italian scenario in a comparative European perspective.

\section{<A>Derivatives: weapons of hedging efficiency, speculative disarray and accounting dissimulation}

What are derivatives? How do they work? Who are the actors using them and why?

According to a standard definition, a derivative contract is 'a financial instrument whose value depends on (or derives from) the values of other, more basic, underlying variables' (Hull, 2009, p. 1). In other words, the value of the derivative stems from the price volatility of its underlying asset. As mainstream textbooks (Hull, 2009; Kolb and Overdahl, 2007) commonly explain, there are four basic or 'plain vanilla' types of derivatives: $<B L>$

- Forwards, which are customised agreements between two parties to buy or sell an underlying asset at a specified price on a future date.

- Futures, which are similar to forwards but are standardised and traded on an organised exchange.

- Options, which are contracts that offers the buyer the right - but not the obligation - to buy (call options) or sell (put options) an underlying 
asset at an agreed-upon price during a certain period of time or on a specific date.

- Finally, swaps are agreements between two parties to exchange the cash flows of different assets at a future date.

Other exotic types of derivatives alter these primary instruments to create more complex and 'synthetic' products.

For a long time in history, contracts similar to forwards, futures and options were traded primarily on agricultural products and commodities (Swan, 1999). However, particularly after the emergence of swaps in the early 1980s (Geisst, 2002, pp. 248-52), derivatives contracts on financial assets became the most widely traded instruments. Listed in descending order according to market size (BIS, 2015), modern derivatives refer to five different categories of underlying assets:

$<B L>$

- Interest rate such as interest rate swaps, interest rate futures and forward rate agreements.

- Foreign exchange rate such as currency swaps, currency futures, currency options and currency forwards.

- Credit such as credit default swaps, total return swaps and collateralised debt obligations.

- Equity such as stock options, warrants, index futures.

- Commodity such as commodity futures, commodity options and commodity swaps. 
Other contracts are also traded on underlying variables such as property indexes, macroeconomic indicators, freight rates, weather forecast, $\mathrm{CO}_{2}$ emissions and so on (Alizadeh and Nomikos, 2012; Sandor, 2012; Smith and Searle, 2010; Gurkaynak and Wolfers, 2006; Jewson and Brix, 2005). This indicates the possibility for derivatives-based techniques to be applied to many aspects of our economic, political, social and cultural reality (Bryan and Rafferty, 2011, 2006; Wigan, 2009; Shiller, 2003).

Derivatives contracts are bought and sold on two types of markets that differ in terms of trading arrangements, procedures and levels of risk. These two markets are: organised exchanges and OTC markets. An organised exchange is a centralised marketplace for buyers and sellers of derivatives contracts. Bids and offers can be based on an open out-cry system or on electronic trading. Today, most of the exchanges trade through computer-based platforms. Organised exchanges offer instruments that are standardised in terms of quantity, quality, expiration months, delivery terms and dates, minimum price fluctuations, daily price limits, trading days and hours. For this reason, contracts can be easily transferable to third parties through the market (Hull, 2009, pp. 1-2).

As Loader (2005) shows, the major benefit of organised exchanges is the use of the central counterparty system of clearing and settlements. Here, the clearing house sells the contract to the buyer and buys it from the seller, intermediating between the two parties by clearing and settling the contract. This method dramatically reduces the risk of default through the system of so-called margins according to which market participants are required to 
register an account with the exchange from which money is withdrawn or credited according to the daily profits and losses. These margins are usually very low compared to the control over large amounts of underlying assets an individual can exert. This means that with a relatively small amount of cash, investors can enter into derivatives worth much more than the required initial margin deposits - a characteristic known as leverage (Hull, 2009, p. 15).

Contrary to organised exchanges, OTC markets are decentralised networks where financial institutions tailor instruments to fit certain requirements of their clients. Due to the benefits of trading custom-made products, OTC markets expanded overwhelmingly compared to formal exchanges. However, these markets have no central clearing house and contracts are instead privately negotiated between the two parties - an aspect which implies a considerably higher exposure to credit risk (Hull, 2009, p. 2). For this reason, initiatives were developed to minimise risk on OTC markets. For instance, contract details are subject to market standard documentation such as the Master Agreement by the International Swaps and Derivatives Association (ISDA). In spite of this, it is evident that OTC markets simply function by linking various trading floors amongst the major financial institutions. There is 'no central mechanism to limit individual or aggregate risk taking, leverage, and credit extension, and risk management is completely decentralized' (Schinasi et al., 2000, p. 19). At the level of transparency, besides semi-annual surveys by central banks, 'information about market concentration and who owns which risks is generally unavailable; at best, a trading desk might know that some institutions are 
building up positions' (Schinasi et al., 2000, p. 19). After the 2008 global financial crisis, regulators pushed for a comprehensive reform of OTC derivatives markets with the objective of increasing transparency and reducing their systemic risk (FSB, 2010, 2014).

Why do derivatives exist? Who are the actors using them? The mainstream argument is that derivatives markets provide a fundamental function of risk management. To appreciate what derivatives-based risk management entails, let us refer to two examples of forward and futures contracts.

Imagine that instead of awaiting the crop to be ready and then trade wheat at the prevailing market price, a farmer and a miller agree in advance on a specific price, quantity and date of delivery of the wheat in the future. ${ }^{1}$ Once the crop is harvested and ready to be sold, the market-prevailing price at harvesting time could be either above or below the price previously agreed on in the contract. The first case favours the miller. In fact, because of the contract, she pays less for the wheat than what she would pay if buying the commodity at the market-prevailing price. The second case favours instead the farmer who, due to the contract, is being paid more that what others pay on the market. In spite of this seemingly one-sided bet against the future price of wheat, both parties gain in business certainty and price stability. In the second half of the nineteenth century, merchants in Chicago revolutionised the modalities of forwards-like contracts and established the first market for futures contracts at the Chicago Board of Trade (CBOT). Futures are contracts in which all details are specified, making it easy to be 
exchanged amongst traders. After the CBOT, other markets for futures soon flourished across the United States (US) (Markham, 2002, pp. 265-9). How does a futures market function?

An organised futures exchange is a centralised marketplace for buyers and sellers of futures contracts. ${ }^{2}$ Let us imagine on 5 March the miller gives instruction to a broker to enter into a future to buy 5000 bushels of wheat in July. In the same period, the farmer instructs another broker to enter into a contract to deliver 5000 bushels of wheat in July. As the party who agrees to buy the commodity, the miller is in the long position (going long). The farmer is instead in the short position (going short) as she agrees to deliver the commodity. Each contract always involves both positions. Under an open outcry system, floor traders would meet up to agree on a price. On an electronic platform instead, brokers would match bids and offers via computer-trading networks. The price agreed - let us say $\$ 4$ per bushel - is the current futures price for July wheat, which is subject to fluctuations in supply and demand.

Conceptually, futures are very similar to forwards since both contracts involve the future delivery of an asset at a price agreed today. However, there are three key differences. First, the two instruments are traded on different markets. Being standardised products, futures are bought and sold on organised exchanges. Second, the miller and the farmer do not meet up personally, but refer to their brokers who in turn relate to the exchange's clearing house as their counterpart. In other words, it is the clearing house which sells the wheat to the miller's broker and buys it from the farmer's 
broker, clearing and settling the contract. Third, and this is a fundamental innovation in derivatives trading, the two parties are not bound to exchange the actual commodity at the expiration of a contract. The majority of futures positions are closed out before being exercised at expiration, making the market for futures work practically through a process of cash settlement (Levy, 2006). Profits and losses are calculated on the basis of the daily price movements of futures, whilst the accounts of both long and short positions are adjusted for gains and losses at the end of each trading day.

Since futures can be easily closed out before expiration, exercising the contract for delivery is very unusual. Closing out a position means entering into a contract that is the opposite of the original one (Hull, 2009, p. 23). For example, the miller - who bought a July wheat futures contract on 5 March can close out the position by instructing the broker to sell one July wheat futures contract on, say, 6 May. The farmer who is in a short position would do the opposite. In both cases, total gain or loss are determined by the difference in the futures prices between the day in which they entered the first contract (5 March for the miller) and the day when the contract is closed out.

To clarify the use of these mechanisms, let us refer to a historical case which is based on the insightful research conducted by Levy (2006, pp. 312-13). In February 1892, Andrew J. Sawyer - a grain trader and CBOT member - testified before the US House Committee on Agriculture during the Hatch bill hearings. This bill sought to curb speculation by restricting futures trading without the actual exchange of the underlying commodity (Markham, 
2002, p. 320). Sawyer explained to the Committee how he used futures markets for hedging purposes: 'suppose we are handling 100,000 bushels a day and we can sell in Minneapolis, Buffalo, Montreal, or New York only 75,000 bushels a day, say that is all we can sell. We have then 25,000 bushels left on our hands which we can not sell, there being no market for it' (House Committee on Agriculture, 1892, p. 31). Sawyer could hold these 25,000 bushels, but what would have happened if after six months the price for wheat had declined even further? In this case, he needed to insure his business against such event. At this point Sawyer could sell wheat futures to traders in the СВОТ pits. If two days after entering into the contract, the current market price was below the contract price, Sawyer would have profited. He would close out his position, obtaining the capital necessary to keep storing the 25,000 bushels. On the contrary, if the futures market price had turned against him, Sawyer would have incurred losses on his futures position. However, in this case, he would have at least delivered the 25,000 bushels of wheat on the cash market, where the actual commodity is bought on the spot.

Sawyer represented a typical example of hedger, a market participant who used futures as a form of insurance against the risk involved in his business operations. In other words, he speculated on futures markets, but only with the intention of either closing out his position before expiration therefore making a profit to be reinvested in his business - or effectively delivering the actual commodity at the end of the contract. Besides hedgers, futures markets attracted many traders who were hardly interested in the 
actual exchange of wheat. In fact, contracts were only rarely exercised at expiration. How did advocates of futures trading justify the presence of speculators in the pits? Although compared to gamblers by the people outside the exchanges, speculators nonetheless appeared to other market participants as essential providers of liquidity. By buying and selling contracts in search for a profitable trend, they went long or short when they anticipated prices to respectively increase or decrease. In so doing, whilst satisfying their thirst for quick profits, speculators made sure that hedgers like Sawyer always found counterparts to their actual trading needs (Levy, 2006, p. 325).

Contemporary literature on derivatives widely acknowledges this distinction between hedgers and speculators. The two broad categories include myriad of market participants such as banks, institutional investors, central banks, governments, companies, wealthy individuals and retail investors. These actors, either directly or indirectly, enter into futures and other derivatives contracts to hedge risk or take risk. ${ }^{3}$ Paradoxically, the two facets are intertwined and support each other.

In this study, I contend that such hedging-speculation dualism is of limited heuristic value because it fails to account for a pivotal dimension of derivatives markets: these instruments provide opportunities to avoid regulation and to window-dress accounting rules. To be sure, as long as we focus on trading in organised exchanges and futures or options as instruments, we can easily explain the use of derivatives-based techniques through the hedging-speculation dichotomy. Yet, things are quite different as 
soon as we examine OTC markets and particularly swaps instruments, a scenario that Partnoy (2009, p. 18) describes as the 'wild Wild West of trading'.

The swaps market expanded dramatically since the 1980s because investors found these tools useful to hedge their risk exposures towards volatility in interest rates and exchange rates (Markham, 2002, p. 192). According to the conventional argument - based on the theory of comparative advantage - the swap market makes possible for both parties to borrow and repay at the globally lowest costs in interest-rate structure and currency (Hull, 2009, pp. 147-76). ${ }^{4}$ To be sure, these features are true to a certain extent. However, as Partnoy (2009, p. 46, my italic) explains in reference to the case of the investment bank Bankers Trust: $<\mathrm{QM}>$

companies would do swaps not necessarily because swaps allocated risk more efficiently, but rather because they were unregulated. They could do swaps in the dark, without the powerful sunlight that securities regulation shined on other financial instruments. And here was the crucial point: to the extent companies and their financial officers could use custom-tailored swaps to avoid regulation or to hide risks, Bankers Trust's profits from selling swaps to those companies might not disappear so quickly. Corporate treasurers hoping to benefit from such swaps would pay a premium - it wasn't their money, after all - if the swaps were structured in a way that created more opportunity for profit, but hid the risks from their bosses. 
In the following sections, I attempt to uncover such dark side of derivatives by exploring the case of Italian municipalities and their use of swaps. I show how swaps can become tools of accounting dissimulation - or, as some financial journalists would put it, ‘weapons of mass deception' (Dunbar 2006; Norris 2013). This aspect is crucial to explain the politically driven and differential expansion of derivatives practices. I base my analysis on previous research results which I published in Lagna (2015).

\section{<A>Italian municipalities and derivatives: a story of political resistance against fiscal austerity}

The historical conditions for Italian local authorities to approach OTC derivatives markets emerged in the mid-1990s. During these years, a domestic alliance between centre-left politicians and neo-liberal-minded technocrats pushed for Italy to join the euro in 1999 by complying with the Stability and Growth Pact (SGP). European integration represented a leverage to their power position because it functioned as an 'external constraint' (Sbragia, 2001; Dyson and Featherstone, 1996) on the country's traditional political-cum-business establishment, which had until then relied on the dissipation of public finance (Pasquino, 2000, p. 79), full control over state-owned industrial and financial apparatus (Bianchi, 1987) and, finally, a 
corporate governance regime that worked to the advantage of private blockholders (Deeg, 2005; McCann, 2000).

At the same time, as Italy faced the imperative to reduce public debt and deficits under the dictates of the SGP (Cafruny and Ryner, 2008; Heipertz and Verdun, 2005, 2004), the neo-liberal coalition also advanced the benefits of a fiscal and administrative decentralisation (Alonso, 2012). The costs and benefits of decentralisation in Italy had been debated since the 1980s, but the process gained momentum only with the first 'Bassanini' law in 1997 (Italian Parliament, 1997). It was eventually finalised with the consolidated law on local authorities in 2000 (Italian Government, 2000) and, eventually, the reform of the constitutional law in 2001 (Italian Parliament, 2001a). The latter granted local authorities wider margins of autonomy in their revenue and expenditure decisions, a process which gradually continued until the present time (Italian Parliament, 2010b). These reforms opened up new scenarios for local authorities by dismantling the old system of subsovereign finance where the central government collected most part of the inland revenues and then transferred funds to local authorities. Moreover, when state transfers were insufficient, local administrators financed their investments through fixed-rate loans from public banks such as Cassa Depositi e Prestiti (Rosati, 2009, p. 4).

Thus, whilst the level of state transfers began to decrease in line with EU-imposed budgetary limits, local authorities gradually obtained more autonomy in the management of their revenue and expenditure flows. In this context, they faced the necessity - or the opportunity - of approaching 
financial markets, instruments and actors beyond the traditional public sphere (Saccomanni, 2007, p. 17). In a word, local authorities began to move within new institutions and discourses of a financialised kind. Derivatives and particularly interest rate swaps emerged as fundamental practices of this new environment. As a council member of a Southern Italian municipality explained in a bizarre comparison, 'swaps became very fashionable ... bank brokers contacted budget assessori relentlessly ... just like solar-panel companies are doing today' (Interview, 31 August 2012, my translation). ${ }^{5}$ The construction of a regulatory framework concerning the use of derivatives in local finance mirrored the course of events. Regulation acknowledged swaps for the first time in 1996. Local authorities were allowed to issue bonds since 1994 and, in this regard, they were obliged to enter into currency swaps contracts when bonds were denominated in foreign currencies (MEF, 1996; Italian Parliament, 1994). Besides this, there was no specific regulation concerning the adoption of other types of swaps up until the period 2001-04 (MEF, 2004, 2003; Italian Parliament, 2001b). ${ }^{6}$ It is only at this point that a specific regulatory regime was put in place to discipline the growing use of derivatives in local finance. Although this regulation was updated in few occasions (Italian Parliament, 2006), its basic pillars remained substantially unchanged until the summer of 2008 when the government enacted a moratorium that prohibited local governments from entering into new contracts (Italian Parliament, 2008a, 2008b). This regulatory architecture can be summarised in the following six features (see Franco, 2009, pp. 18-22, 46; Rosati, 2009, pp. 9-11, 15-18): 
$<\mathrm{BL}>$

- Local authorities were allowed to use derivatives only to hedge existing liabilities and not for speculative purposes.

- They were obliged to use currency swaps when issuing bonds in foreign currencies, as well as amortising swaps when issuing bonds (or taking out loans) with single repayments at maturity.

- They were allowed to use currency swaps, interest rate swaps, forward rate agreements, amortizing swaps and interest rate options (caps, collars).

- They could have restructured their debt positions but could not have done so with the objective of postponing the maturity of the initial debt. Moreover, these operations could not have included an upfront sum above 1 per cent of the notional amount or an increasing flow of payments by the local authority to the counterparty over the duration of the contract.

- Local governments were obliged to enter into contracts with highly creditworthy dealers only and by using financial and monetary parameters belonging to G7-area. Moreover, for contracts of approximately $€ 100$ million (notional value), they should have limited exposure to a single intermediary at 25 per cent of the total notional amount.

- The Ministry of Economy and Finance (MEF) was responsible for monitoring derivatives activities every three months. Bank of Italy and the Italian securities market authority (CONSOB) were both 
responsible for controlling financial intermediaries and their derivatives operations with local authorities.

At this point, a key question arises: Why did local authorities adopt derivatives? Under growing financial constraints, they attempted to make a virtue of the new financialised practices. The mainstream economic understanding shows that these actors aimed at optimising the costs of the debt portfolio by restructuring the debt position. This was done in the attempt to free part of those financial resources that were previously used to serve the debt, therefore generating more liquidity in the budget at a time in which the latter was drying up.

For instance, a municipality in the Apulia region decided to restructure its debt by closing over 60 fixed-rate loans - of the total value of over $€ 10$ millions - which were contracted with Cassa Depositi e Prestiti in the period 1997-2004. ${ }^{7}$ At the same time, the municipality issued municipal bonds known in Italy as buoni ordinari comunali (BOC) at a fixed rate of 3.75 per cent for the same value and with a 20-year maturity. A specialised bank assisted the issuing process in all its phases and underwrote the entire lot of bonds. In other words, the municipality had the opportunity to extinguish its debt - in the form of loans - and issued bonds to 'catch the opportunity arising from favourable levels of market rates' (Interview, 4 September 2012, my translation). The interest rate swap entered the picture in 2006. How did it work in practice?

The very same bank proposed the municipality to enter into a fixed-tofloating interest rate swap. It is important to remember that this swap did not 
substitute the previous commitments that the municipality had on the 20 year-maturity bond. It was instead a separate contract that worked like a bet where the bank was the fixed-rate payer and the municipality was the floating-rate payer. In this type of swap, the nature of the bet was that the fixed-rate payer had a negative flow of funds towards the floating-rate payer when the interest rate went down and vice versa. Due to the interest-rate scenarios, the municipality had initially a positive flow of funds. In practical terms, the municipality still paid a fixed-rate of $3.75 \%$ on its bonds, but this interest was discounted of certain basis points in line with the funds that derived from the swap bet in variable terms. However, as interest rates rose, the initial positive flows turned negative for the municipality. ${ }^{8}$ Hence, the opportunity was not as attractive as it had been in the beginning.

Apart for the common economic rationale behind the use of derivatives by local authorities, there is another dimension of the story that relates to the Italian power relations. This story clearly highlights the politicised strategies of Italian local governments and how they attempted to challenge the neoliberal institutions of fiscal austerity as constructed since the 1990s. In fact, by looking at several specific cases of municipalities, it becomes clear that the latter employed interest rate swaps because of a key accounting element, namely: the upfront.

This is a sum that the bank advanced to a given municipality to set the contract in a market-neutral position. It happened when the swap was of a 'non-par' type, meaning that, when the two parties entered into the contract, the swap presented a negative market value for one of the two parties - in 
this case, the municipality. As a result, the bank brought the contract to a par condition by advancing an upfront sum to the municipality which should be equivalent to the negative market value the local government was exposed to at the signing of the contract (Rosati, 2009, pp. 1-2). This aspect presented a crucial accounting artifice. Municipalities considered the upfront as a revenue rather than a debt. For this reason, they circumvented the budget constraint of 15 per cent of the debt-to-revenue ratio as imposed by the patto di stabilità interno - that is, the domestic equivalent of the SGP. In other words, local governments inflated the revenue side of the ratio whilst leaving the debt-side unchanged. Paradoxically, the upfront turned into a virtue to be potentially used for creating mass consensus at a local level (Carlini, 2010). Indeed, as Sanderson, Dinmore and Tett (2010) pointed out: $<\mathrm{QM}>$

In the revolving-door world of Italian local politics, each new administration wanted its own upfront, so asked their bankers to restructure the deal to release more cash in advance. The terms of the swap tended to become more restrictive each time. Some banks covered the cost of the upfront fee by pricing the interest rate swap more aggressively, so that only in unusual circumstances would the entity receive more each period than it paid out.... In other cases, upper and lower limits on the movement of interest rates ensured the upside for the local authorities was reduced and downside risks were magnified. 


\section{$<A>$ Current trajectories in Italy and other European countries}

When the global financial crisis occurred in 2008, Italian local authorities had

already spurred a heated controversy concerning their use of financial derivatives, particularly owing to the substantial losses they incurred.

According to data from the Bank of Italy (Bankitalia, 2009, p. 22; 2014, p. 22), 349 local governments - including regions, provinces and municipalities had a negative mark-to-market exposure to derivatives of $€ 600$ million in December 2005. This figure increased to 600 local authorities with a negative market value of $€ 737$ million by December 2006. In December 2008, the number of local governments declined to 474 but the negative market value went up to approximately $€ 1$ billion. Since then, although the number of local authorities with currently open derivatives positions declined, the amount of losses increased to above $€ 1.2$ billion in June 2014 (latest data available), with a peak of $€ 1.5$ billion in December 2012. It is important to note that these data only concern the activities of financial intermediaries that operate in Italy. Yet, larger local authorities typically contracted with foreign operators, which account for an approximately 60 per cent market share. In other words, the data represent an approximation that underestimates a much broader phenomenon (Franco, 2009, pp. 26-7). Losses could even reach $€ 10$ billion according to the Financial Times (Sanderson et al., 2010). In this context, the government imposed the above-mentioned moratorium that 
prevented local administrations from entering into derivatives contracts until a new regulation was agreed upon.

After this, the events concerning the use of derivatives in local finance evolved along two major paths. First, regions, provinces and municipalities either closed out their contracts - in the majority of cases, at a loss - or filed lawsuits against financial intermediaries in the attempt to invalidate their contracts. Media became very attentive to several trials involving major cities, most notably Milan (Sirletti and Martinuzzi, 2014; Martinuzzi, 2013). Second, regulators began to work on a new regulatory framework to discipline the matter whilst the parliament led a two-year investigation on the matter (Italian Parliament, 2010a). In September 2009, MEF (2009) released a provisional draft of this regulation that was also discussed by the parliament. The draft focused on three main aspects: $<\mathrm{QM}>$

- The types of derivatives contracts available to local authorities.

- The derivatives components that local authorities could have included in their financing strategies.

- The transparency of information to be presented both in the contract profiles and the annual budget report.

Although the first two dimensions did not present substantial innovations, the last aspect concerning transparency implied instead important changes. To begin with, besides being obliged to communicate to the client the par value and the implicit costs of the contract at least every three months, intermediaries were supposed to include in the contract profile elements 
such as: a full description in Italian language of all the contract details; the par value at the start of the contract; an analytical description of all the factors that constitute not only the derivative instrument per se, but the entire portfolio in which the derivative contract is included; a numerical simulation about the implicit cost of the contract - this aspect led to a controversial debate between those who preferred probability analysis and the Italian Banking Association (ABI) which proposed instead sensitivity analysis (Italian Parliament, 2011). In addition to this, the new regulation increased also the controls over the specific procedures that local administrators would undertake when using derivatives. In this regard, municipal treasures had to indicate - both in the annual budget report for the next year (bilancio di previsione) and for the previous year (rendiconto) - the full picture of derivatives activities, including: the type of operation; the notional principal amount; the underlying liability; the past and expected negative and positive flow of payments. Furthermore, local authorities had to indicate the ratio between the debt that the derivative operation refers to and the total debt position. Finally, they were required to establish a so-called 'risk fund' to cover the negative payments which could incur in the derivatives positions. Eventually, owing to its complexity, the debate reached a stalemate. Thus, in December 2013 - five years after the enactment of the moratorium the short-lived government led by Enrico Letta opted to permanently prohibit local authorities from using derivatives, leaving only the possibility to use interest rate caps on their actual loans (Italian Parliament, 2013). This solution is similar to the British case where local authorities are prohibited from 
entering into derivatives transactions because they do not possess the necessary knowledge and skills. The House of Lord took this exemplary decision in 1989 after the London borough of Hammersmith and Fulham incurred losses of several hundred million pounds in one of the most infamous derivatives fiascos (Geisst, 2002, pp. 260-3). ${ }^{9}$

Whilst Italian regulators took this course of action, other European member states did not follow it and still allow local governments to embrace financial innovation. This is the case despite the fact that large derivatives debacles involving municipalities occurred in countries such as Germany and France (Dodd, 2010) - see for instance the City of Saint Etienne (Katz, 2010) and Pforzheim (Hendrikse and Sidaway, 2013).

\section{$<A>$ Concluding remarks}

Alan Greenspan (2003) - Chairman of the US Federal Reserve System from 1987 until 2006 - commented on the global growth of derivatives markets with the following words:

$<\mathrm{QM}>$

For at least the past twenty years, the process of financial globalization has been rapidly advancing. The development of new financial products, notably a wide variety of OTC derivatives, and the removal of many barriers to international capital mobility have tightened linkages among global financial markets. As a result, capital 
has flowed more freely across national borders in search of the highest risk-adjusted rates of return. At some point, globalization undoubtedly will reach maturity. Financial innovation will slow as we approach a world in which financial markets are complete in the sense that all financial risks can be efficiently transferred to those most willing to bear them.

This perspective is common amongst mainstream financial theorists, who understand the striking expansion of derivatives in the light of how these instruments give investors the tools necessary to hedge risk in a calculated manner. Derivatives are fundamental to make financial markets 'complete' in the theoretical sense given by Arrow and Debreu (1954).

Against this view, I have contended that it is necessary to transcend the orthodox narrative on derivatives to explore the actual politics and power relations underlying the global spread of modern financial innovation. In fact, the striking growth of derivatives is a global process that unfolds differentially depending on context-specific political struggles. To substantiate this argument, I have attempted to explore the 'underbelly' of derivatives markets, a scenario that is made of regulatory arbitrage and accounting dissimulation. Wielding derivatives as ‘weapons of mass deception' (Dunbar, 2006; Norris, 2013) is a very useful practice in the context of power conflicts. After this, I have focused on the case of local governments in Italy and how they employed derivatives to challenge the regime of fiscal austerity that - 
imposed by domestic neoliberal forces since the 1990s - left local

communities at the end of their tether.

\section{$<$ A $>$ References}

Alizadeh, A.H. and Nomikos, N.K. (2012) 'Ship Finance: Hedging Ship Price Risk Using Freight Derivatives'. In Talley, W. (ed.) The Blackwell Companion to Maritime Economics. Chichester: Wiley \& Sons, pp. 433-51.

Alonso, S. (2012) Challenging the State: Devolution and the Battle for Partisan Credibility: A Comparison of Belgium, Italy, Spain, and the United Kingdom. Oxford: Oxford University Press.

Arrow, K. and Debreu, G. (1954) 'Existence of an Equilibrium for a Competitive Economy', Econometrica, 22 (3): 265-90.

Bankitalia (2009) Debito Delle Amministrazioni Locali. Rome: Bank of Italy. Retrieved on 15 December 2015 from www.bancaditalia.it/pubblicazioni/debito-amministrazioni/.

Bankitalia (2014) Debito Delle Amministrazioni Locali. Rome: Bank of Italy. Retrieved on 15 December 2015 from www.bancaditalia.it/pubblicazioni/debito-amministrazioni/.

Bianchi, P. (1987) 'The IRI in Italy: Strategic Role and Political Constraints', West European Politics, 10 (2): 269-90.

BIS. 2015. OTC derivatives statistics at end-June 2015. Basel: Bank for International Settlements. Retrieved on 15 december 2015 from www.bis.org/publ/otc_hy1511.pdf.

Bryan, D. and Rafferty, M. (2006) Capitalism with Derivatives. A Political Economy of Financial Derivatives, Capital and Class. Basingstoke: Palgrave Macmillan.

Bryan, D. and Rafferty, M. (2011) 'Deriving Capital's (and Labour's) Future', Socialist Register, 47: 196-223.

Cafruny, A.W. and Ryner, M.J. (2008) 'Is the SGP Crisis Also the Crisis of the EU? Assessing the EMU from a Structural, Transatlantic Perspective'. In Talani L. and Casey, B. (eds) Between Growth and Stability. The Demise and Reform of the European Union's Stability and Growth Pact. Cheltenham: Edward Elgar, pp. 60-84. 
Carlini, V. (2010) 'Ecco Come La Finanza Creativa Ha Danneggiato Gli Enti Pubblici', II Sole 24 Ore, 22 March. Retrieved on 15 December 2015 from www.ilsole24ore.com/art/SoleOnLine4/Finanza\%20e\%20Mercati/2010/03/de rivati-comuni-truffa-raggiro-ente-pubblico-P_A.shtml.

Deeg, R. (2005) 'Remaking Italian Capitalism? The Politics of Corporate Governance Reform', West European Politics, 28 (3): 521-48.

Dodd, R. (2010) 'Municipal Bombs', Finance \& Development, 47 (2): 33-5.

Dunbar, N. (2006) Risky Finance: Weapons of Mass Deception. Retrieved on 15 December 2015 from www.nickdunbar.net/articles-and-reviews/riskyfinance-weapons-of-mass-deception/.

Dunbar, N. (2014) Lost Lobos. Retrieved on 15 December 2015 from http://nickdunbar.net/2014/10/24/lost-lobos/.

Dyson, K. and Featherstone, K. (1996) 'Italy and EMU as a "Vincolo Esterno": Empowering the Technocrats, Transforming the State', South European Society and Politics, 1 (2): 272-99.

Engelen, E. (2008) 'The Case for Financialization', Competition \& Change, 12 (2): 111-19.

Franco, D. (2009) Indagine Conoscitiva sull'Utilizzo e La Diffusione degli Strumenti di Finanza Derivata e delle Cartolarizzazioni nelle Pubbliche Amministrazioni. Rome: Italian Senate. Retrieved on 15 December 2015 from www.bancaditalia.it/pubblicazioni/interventi-vari/int-var2009/Audizione_Senato_080709.pdf.

FSB (2010) Implementing OTC Derivatives Market Reforms. Basel: Financial Stability Board. Retrieved on 15 December 2015 from www.financialstabilityboard.org/2010/10/fsb-report-on-implementing-otcderivatives-market-reforms.

FSB (2014) Overview of Progress in the Implementation of the G20 Recommendations for Strengthening Financial Stability. Basel: Financial Stability Board. Retrieved on 15 December 2015 from www.financialstabilityboard.org/2014/11/overview-of-progress-in-theimplementation-of-the-g20-recommendations-for-strengthening-financialstability-5.

Geisst, C.R. (2002) Wheels of Fortune. The History of Speculation from Scandal to Respectability. Hoboken: Wiley.

Greenspan, A. (2003) Global Finance: Is It Slowing? Remarks by Chairman Alan Greenspan at the Banque de France International Symposium on Monetary Policy, Economic Cycle, and Financial Dynamics, Paris, France. Retrieved on 15 December 2015 from www.federalreserve.gov/BOARDDOCS/SPEECHES/2003. 
Gurkaynak, R. and Wolfers, J. (2006) 'Macroeconomic Derivatives: An Initial Analysis of Market-Based Macro Forecasts, Uncertainty, and Risk', NBER Working Paper No. 11929.

Heipertz, M. and Verdun, A. (2004) 'The Dog That Would Never Bite? What We Can Learn from the Origins of the Stability and Growth Pact', Journal of European Public Policy, 11 (5): 765-80.

Heipertz, M. and Verdun, A. (2005) 'The Stability and Growth Pact Theorizing a Case in European Integration', Journal of Common Market Studies, 43 (5): 985-1008.

Hendrikse, R.P. and Sidaway, J.D. (2013) 'Financial Wizardry and the Golden City: Tracking the Financial Crisis through Pforzheim, Germany', Transactions of the Institute of British Geographers, 39 (2): 195-208.

House Committee on Agriculture (1892) Fictitious Dealing in Agricultural products. Testimony Taken before the Committee on Agriculture during a Consideration of Bills Nos. 392, 2699, and 3870, Restricting and Taxing Dealers in Futures and Options in Agricultural Products, and for Other Purposes. Washington, DC: United States House Committee on Agriculture.

Hull, J.C. (2009) Options, Futures and Other Derivatives. Upper Saddle River, $\mathrm{NJ}$ : Pearson Prentice Hall.

Italian Government (1998) Law Decree No. 58 (24 February). Retrieved on 15 December 2015 from www.normattiva.it.

Italian Government (2000) Law Decree No. 267 (18 August). Retrieved on 15 December 2015 from www.normattiva.it.

Italian Parliament (1994) Law No. 724 (23 December), Article 35. Retrieved on 15 December 2015 from www.normattiva.it.

Italian Parliament (1997) Law No. 59 (15 March). Retrieved on 15 December 2015 from www.normattiva.it.

Italian Parliament (2001a) Constitutional Law No. 3 (8 October). Retrieved on 15 December 2015 from www.normattiva.it.

Italian Parliament (2001b) Law No. 448 (28 December), Article 41. Retrieved on 15 December 2015 from www.normattiva.it.

Italian Parliament (2006) Law No. 296 (27 December), Article 1 (736-739). Retrieved on 15 December 2015 from www.normattiva.it.

Italian Parliament (2008a) Law No. 133 (6 August). Retrieved on 15 December 2015 from www.normattiva.it. 
Italian Parliament (2008b) Law No. 203 (22 December), Article 3. Retrieved on 15 December 2015 from www.normattiva.it.

Italian Parliament (2010a) Indagine Conoscitiva sull'Utilizzo e La Diffusione degli Strumenti di Finanza Derivata e delle Cartolarizzazioni nelle Pubbliche Amministrazioni (Documento Conclusivo) Rome: Italian Senate. Retrieved on 15 December 2015 from www.parlamento.it/service/PDF/PDFServer/BGT/470072.pdf.

Italian Parliament (2010b) Indagine Conoscitiva Sulla Finanza Locale. Rome: Italian Chamber of Deputies. Retrieved on 15 December 2015 from http://documenti.camera.it/_dati/leg16/lavori/documentiparlamentari/indiceet esti/017/009/intero.pdf.

Italian Parliament (2011) Resoconto Stenografico No. 19. Rome: Italian Senate. Retrieved on 15 December 2015 from www.senato.it/service/PDF/PDFServer/DF/253243.pdf.

Italian Parliament (2013) Law No. 147 (27 December), Article 1 (572). Retrieved on 15 December 2015 from www.normattiva.it.

Jewson, S. and Brix, A. (2005) Weather Derivative Valuation: The Meteorological, Statistical, Financial And Mathematical Foundations. Cambridge: Cambridge University Press.

Katz, Alan. (2010) 'The City That Got Swapped', Bloomberg, 22 April. Retrieved on 15 December 2015 from www.businessweek.com/magazine/content/10_18/b4176100989666.htm.

Kolb, R.W. and Overdahl, J.A. (2007) Futures, Options, and Swaps. Oxford: Blackwell.

Konings, M. (2010), 'The Pragmatic Sources of Modern Power', European Journal of Sociology, 51 (1): 55-91.

Lagna, A. (2015) 'Italian Municipalities and The Politics of Financial Derivatives: Rethinking the Foucauldian Perspective', Competition \& Change, 19 (4): 283-300.

Levy, J.I. (2006) 'Contemplating Delivery: Futures Trading and the Problem of Commodity Exchange in the United States, 1875-1905', The American Historical Review, 111 (2): 307-35.

Loader, D. (2005) Clearing and Settlement of Derivatives. Burlington: Elsevier. MacKenzie, D. (2003) 'Long-Term Capital Management and the Sociology of Arbitrage', Economy and Society, 32 (3): 349-80. 
Markham, J.W. (2002) A Financial History of the United States. From Christopher Columbus to the Robber Barons (1492-1900). Armonk: M.E. Sharpe.

Martinuzzi, E. (2013) 'JPMorgan, UBS Tricked Milan in Swaps Case, Judge Says', Bloomberg, 4 February. Retrieved on 15 December 2015 from www.bloomberg.com/news/2013-02-04/jpmorgan-deutsche-bank-trickedmilan-in-swaps-case-judge-says.html.

McCann, D. (2000) 'The 'Anglo-American' Model, Privatization and the Transformation of Private Capitalism in Italy', Modern Italy, 5 (1): 47-61.

MEF (1996) Ministerial Decree No. 420 (5 July). Retrieved on 15 December 2015 from

www.dt.tesoro.it/it/debito_pubblico/enti_locali/nota_espl_normativa_enti_terri toriali.html.

MEF (2003) Ministerial Decree No. 389 (1 December). Retrieved on 15 December 2015 from

www.dt.tesoro.it/it/debito_pubblico/enti_locali/nota_espl_normativa_enti_terri toriali.html.

MEF (2004) MEF Memorandum No. 128 (27 May). Retrieved on 15 December 2015 from

www.dt.tesoro.it/it/debito_pubblico/enti_locali/nota_espl_normativa_enti_terri toriali.html.

MEF (2009) Schema di Regolamento Ministeriale di Attuazione dell'Articolo 62 del Decreto Legge 25 Giugno 2008, N. 112, Convertito con Modificazioni dalla Legge 6 Agosto 2008, N. 133, come Sostituito dall'Articolo 3 della Legge 22 Dicembre 2008, N. 203 (Documento di Consultazione). Retrieved on 15 December 2015 from www.dt.tesoro.it/export/sites/sitodt/modules/documenti_it/regolamentazione _bancaria_finanziaria/consultazioni_pubbliche/Derivati_enti_locali__regolamento_ex_articolo_62_d.I.pdf.

Nölke, A., Heires, M. and Bieling, H.J. (2013) 'Editorial: The Politics of Financialization', Competition \& Change, 17 (3): 209-18.

Norris, F. (2013) 'Wielding Derivatives as a Tool for Deceit', The New York Times, 27 June. Retrieved on 15 December 2015 from www.nytimes.com/2013/06/28/business/deception-by-derivative.html.

Partnoy, F. (2009) Infectious Greed. How Deceit and Risk Corrupted Financial Markets. New York: PublicAffairs.

Pasquino, G. (2000) 'Political Development'. In McCarthy, P. (ed.) Italy since 1945. Oxford: Oxford University Press, pp. 69-94. 
Rosati, A. (2009) Indagine Conoscitiva sulla Diffusione degli Strumenti di Finanza Derivata e delle Cartolarizzazioni nelle Pubbliche Amministrazioni. Rome: Italian Senate. Retrieved on 15 December 2015 from www.consob.it/documenti/Pubblicazioni/Audizioni/audizione_rosati_2009031 8.pdf.

Saccomanni, F. (2007) Le Problematiche Relative agli Strumenti Finanziari Derivati. Rome: Italian Chamber of deputies. Retrieved on 15 December 2015 from www.bancaditalia.it/pubblicazioni/interventi-direttorio/int-dir2007/saccomanni_061107.pdf.

Sanderson, R., Dinmore, G. and Tett, G. (2010) 'Finance: An Exposed Position', Financial Times, 8 March. Retrieved on 15 December 2015 from www.ft.com/cms/s/0/0d29fbdc-2aef-11df-886b00144feabdc0.html\#axzz2Ldv9pQZa.

Sandor, R. (2012) Good Derivatives: A Story of Financial and Environmental Innovation. Hoboken: Wiley.

Sbragia, A. (2001) 'Italy Pays for Europe: Political Leadership, Political Choice, and Institutional Adaptation'. In Green Cowles, M., Caporaso, J. and Risse, T. (eds) Transforming Europe. Europeanization and Domestic Change. Ithaca: Cornell University Press, pp. 79-96.

Schinasi, G.J. et al. (2000) Modern Banking and OTC Derivatives Markets. The Transformation of Global Finance and Its Implications for Systemic Risk. Washington, DC: International Monetary Fund.

Shiller, R.J. (2003) The New Financial Order. Risk in the 21st Century. Princeton, NJ: Princeton University Press.

Sirletti, S. and Martinuzzi, E. (2014) 'JPMorgan, UBS Convictions Overturned in Milan Swaps Case', Bloomberg, 7 March. Retrieved on 15 December 2015 from www.bloomberg.com/news/2014-03-07/jpmorgan-ubs-convictionsoverturned-in-milan-swaps-case.html.

Smith, S.J. and Searle, B.A. (2010) The Blackwell Companion to the Economics of Housing: The Housing Wealth of Nations. Chichester: Wiley \& Sons.

Swan, E.J. (1999) Building the Global Market, a 4000 Year History of Derivatives. London: Kluwer Law International.

Valdez, S. and Molyneux, P. (2013) An Introduction to Global Financial Markets. Basingstoke: Palgrave.

Wigan, D. (2009) 'Financialisation and Derivatives: Constructing an Artifice of Indifference', Competition \& Change, 13 (2): 157-72. 


\section{$<$ A $>$ Notes}

${ }^{1}$ The example of forward contracts is based on Bryan and Rafferty (2006, p. 41).
2 The example of futures contracts is based on Hull (2009, pp. 21-43).
${ }^{3}$ Besides hedgers and speculators, there are also market participants - known as
arbitrageurs - who attempt to identify valuation discrepancies and profit from them (Hull, 2009, pp. 14-15; MacKenzie, 2003).

${ }^{4}$ The theory of comparative advantage applied to a fixed-to-floating interest rate swap would work in the following way - the example is based on Hull (2009, pp. 147-76) and Valdez and Molyneux (2013, pp. 434-41). Imagine that company A and company B need to borrow funds. $A$ is able to borrow more cheaply than $B$ at either a fixed or floating interest rate, but has a greater comparative advantage in a fixed interest rate. Yet, $A$ would prefer borrowing at a floating interest rate. On the contrary, B prefers a fixed interest rate but owing to its lower credit rating - such fixed rate is not as attractive as the floating one. To sum up the hypothetical scenario: (a) A can raise fixed-rate funds at $7 \%$ or floating at the LIBOR rate. A prefers floating interest rate, but has a comparative advantage on fixedinterest-rate borrowing; (b) $B$ has to pay a fixed interest rate of $10 \%$, whilst can borrow floating at the LIBOR rate $+1 \%$. Company $B$ prefers fixed interest rate, but the floating rate is cheaper than the fixed one. Hence, A raises funds from its lender at $7 \%$ fixed interest rate, whilst $B$ borrows from its lender at a floating rate equal to the LIBOR rate $+1 \%$. However, both companies decide to enter into an interest rate swap on a given notional principal amount - which will not be exchanged - and for a given period of time. The terms of such swap agreement are the following: (a) $A$ agrees to pay $B$ the floating rate which equals to the LIBOR rate; (b) $B$ agrees to pay, let us suppose, $8 \%$ fixed interest rate to $A$. In other words, the swap allows: (a) A to pay $7 \%$ fixed interest rate to its lender, but the company receives $8 \%$ fixed interest rate from $B$. This is a profit of $1 \%$ which in actual terms makes A pay $B$ the LIBOR rate $-1 \%$ - even less that what $A$ would pay if the company borrowed funds directly with at a floating interest rate; (b) $B$ pays LIBOR rate $+1 \%$ to its lender, but receives the LIBOR rate from $A$. This is a cost of $1 \%$ which adds up to the $8 \%$ fixed interest rate $B$ pays to $A$, for a total of $9 \%$ fixed interest rate. This last rate is still less than the $10 \%$ fixed interest rate $\mathrm{B}$ was required to pay if the company had borrowed funds directly at a fixed rate.

Please note that the swap contract is distinct from the respective contracts in which the two companies previously enter into. In other words, A still pays its fixed interest rate of $7 \%$ and B pays LIBOR $+1 \%$. The example above is simplified to the extent that it does not take into account of differences in interest rates which are in reality of a few basis points. Moreover, this simplified case does not consider the fundamental role of financial intermediaries. In reality, A and B would not contact each other directly to arrange the swap, but each would deal with a swap dealer.

${ }^{5}$ The interviewee agreed that the information given to me was not be individually ascribed. Italian municipalities are governed by a mayor (sindaco), a municipal executive (giunta comunale) and a municipal council (consiglio comunale) as the legislative body. The interviewee refers to the assessori comunali who are the members of the executive. Each assessore has responsibility for a specific department such as budget, urban affairs, sport and so on. Council members are instead known as consiglieri comunali.

${ }^{6}$ The use of derivatives by private actors was instead regulated by the 1998 consolidated law on finance (Italian Government, 1998).

${ }^{7}$ The following case is based on two interviews (4-5 September 2012) with the head of the financial services of the municipality in question, as well as the official documents that were kindly provided by the interviewee after request to the mayor. The interviewee agreed that the information given to me was not be individually ascribed and the name of the municipality was not to be mentioned - although the official documents concerning the specific swap operation are publicly available via request to the mayor.

${ }^{8}$ From 2009 onwards, interest-rate scenarios changed and started approaching $0 \%$. However, the municipality kept loosing money due to the interest-rate collar. The specific interest rate was the 6-month Euribor. 
${ }^{9}$ See Dunbar (2014) for an analysis of how several banks circumvented British regulation by embedding derivatives inside contracts known as lender option borrower option (LOBO). 